\title{
Immunoglobulin Classes of DNA Binding Activity in Serum and Skin in Systemic Lupus Erythematosus
}

\author{
James B. Pennebaker, James N. Gilliam, and Morris Ziff, Department \\ of Internal Medicine, University of Texas Health Science Center, \\ Dallas, Texas 75235
}

\begin{abstract}
A B S T RAC T 36 systemic lupus erythematosus patients with native DNA binding activity (nDNA-BA) in the serum and subepidermal immunoglobulin deposits were studied to determine the relationship of the immunoglobulin (Ig) class distribution of serum nDNA-BA to the clinical characteristics of their disease and to the Ig class present at the dermal-epidermal junction (DEJ). The patients with predominantly (8698\%) IgM nDNA-BA in the serum had less active disease, mild or no renal involvement, and longer survival than those with predominantly (51-95\%) IgG nDNA-BA in the serum. Renal biopsies in eight patients with predominantly IgM nDNA-BA in the serum showed relatively benign histologic changes in the kidney. In contrast, renal tissue from 23 patients with predominantly IgG nDNA-BA showed more severe histologic changes. All patients had multiple skin biopsies. Patients with predominantly IgM nDNA-BA consistently had only IgM at the DEJ. Patients with predominantly IgG nDNA-BA had IgG, usually in association with IgM, at the DEJ. The findings demonstrate that a minority of systemic lupus erythematosus patients may exhibit a limited antinDNA response characterized by the presence of chiefly IgM nDNA-BA in the serum and that this is reflected by the presence of mild disease and IgM alone at the DEJ. The development of IgG nDNA-BA is associated with more severe and active disease.
\end{abstract}

\section{INTRODUCTION}

Antibodies specific for native double-stranded DNA are characteristic of systemic lupus erythematosus

\footnotetext{
Presented, in part, at the Annual Scientific Meeting of The American Rheumatism Association, Chicago, Ill., 10-11 June 1976.

Dr. Ziff is a recipient of a Research Career Award; Dr. Gilliam is a recipient of Research Career Development Award AM-00278; Dr. Pennebaker was the recipient of Research Fellowship AM-01394 (all from the U. S. Public Health Service).

Received for publication 16 March 1977 and in revised form 1 August 1977.
}

(SLE). ${ }^{1}$ Such antibodies play a role in some of the tissue injury that occurs in this disease and are generally associated with disease activity, renal involvement, and a poorer prognosis $(1,2)$. Results of elution studies in patients with lupus nephritis have indicated that DNAanti-DNA complexes are deposited in the glomerulus in this disease (2).

Antibodies to nuclear antigens in SLE are heterogeneous and may variably react with single- or doublestranded DNA, RNA, nucleoprotein, or polynucleotides (3). They may be found in each of the major immunoglobulin classes (4) as well as IgG subclasses (5). A predominance of IgG antibodies high in complement-fixing activity has been observed among antinuclear antibodies in patients with active nephritis (6). Koffler et al. (2) found that active lupus nephritis was associated with deposition of 7S anti-DNA in the glomerulus, and Rothfield and Stollar (7) reported a close correlation between IgG antinuclear antibodies staining in a peripheral pattern, complement-fixing antibodies to DNA, and the presence of active disease. However, not all patients with SLE have detectable anti-DNA antibodies and some who have such antibodies do not have renal disease (6).

The diversity and heterogeneity of autoantibodies in SLE implies that as yet unidentified factors, such as genetic or viral factors, may restrict or define the immunologic responses of individual patients. Recently Papoian et al. (8) observed that male NZBxNZW $F_{I}$ hybrid $(B / W)$ mice, which have more benign disease and longer survival than the female mice, demonstrate a late development of IgG anti-DNA antibody. Gilliam (9) has moreover observed that the class of Ig deposited at the dermal-epidermal junction (DEJ) in $\mathrm{B} / \mathrm{W}$ mice parallels these observations in the serum. Thus, it seems likely that factors which control the nature of the anti-DNA response in SLE may influence the prognosis of the disease.

\footnotetext{
${ }^{1}$ Abbreviations used in this paper: DEJ, dermal-epidermal junction; nDNA-BA, native DNA binding activity; SLE, systemic lupus erythematosus.
} 
In the present study, the Ig classes of native DNA binding activity (nDNA-BA) in the serum of SLE patients were determined and compared with the clinical and laboratory features of the patients as well as with the classes of Ig deposited at the DEJ.

\section{METHODS}

Patients. 36 patients who satisfied the preliminary criteria for the diagnosis of SLE (10) and additional criteria required for this study were examined by one or more of the authors over a period of approximately $5 \mathrm{yr}$. The additional criteria were as follows: $(a)$ presence of antibodies to native DNA on at least one occasion; $(b)$ presence of Ig deposits at the DEJ of clinically normal skin; $(c)$ absence of significant amounts of anti-ribonucleoprotein antibody in the serum; and $(d)$ absence of advanced renal failure or history of treatment with cytotoxic agents at the time initially studied. The mean age of the SLE patients was $28.4 \mathrm{yr}(13-59 \mathrm{yr})$. 30 were females and 6 males; 28 were black, 6 were white, and 2 were Latin-American. Duration of disease was $16.6 \mathrm{mo}(2-60 \mathrm{mo})$. Duration of follow-up was $27.3 \mathrm{mo}(6-56 \mathrm{mo}) .11$ were receiving prednisolone at the time of study in an average dosage of $25 \mathrm{mg} /$ day.

Skin biopsy and immunofluorescent studies. 3-mm punch biopsies were obtained from the light protected uninvolved skin of the medial surface of the volar forearm. Processing of the tissue and immunofluorescent tests were carried out as previously described (11).

DNA preparations. The labeled DNA used was a purified thymine $\left[2-{ }^{14} \mathrm{C}\right]$ Escherichia Coli $\mathrm{DNA}$ (sp act $37 \mu \mathrm{Ci} / \mathrm{mg}$ ) obtained from Amersham/Searle Corp., Arlington Heights, Ill. The unlabeled DNA used was a highly polymerized calf thymus DNA obtained from Worthington Biochemical Corp., Freehold, N. J.

Determinations of native DNA binding activity. Serum was decomplemented by heating in a water bath at $56^{\circ} \mathrm{C}$ for 30 min. nDNA-BA was determined on whole serum, serum depleted of IgG or IgM by immunoabsorption or on individual Sephadex G-200 fractions (Pharmacia Fine Chemicals, Inc., Piscataway, N. J.) by a modification of the Millipore filter method of Ginsburg and Keiser (12). $25 \mu \mathrm{l}$ of serum, $50 \mu \mathrm{l}$ of immunoabsorbed serum, or $200 \mu \mathrm{l}$ of Sephadex G-200 fractions were incubated at $37^{\circ} \mathrm{C}$ for $30 \mathrm{~min}$ with $0.1 \mathrm{ml}$ of $0.15 \mathrm{M}$ Tris-HCl buffer, pH 7.5, containing $1.0 \mu \mathrm{g}$ unlabeled DNA and $0.03 \mu \mathrm{g}\left[{ }^{14} \mathrm{C}\right] \mathrm{DNA}$ which had been filtered twice through cellulose ester filters (Millipore HAWP, $0.45 \mu \mathrm{m} / 25 \mathrm{~mm}$, Millipore Corp., Bedford, Mass.). After incubation the samples were filtered by gentle suction through $0.45-\mu \mathrm{m}$ Millipore cellulose ester filters. After washing twice with citrated sodium chloride and once with water, the filters were dried overnight at $60^{\circ} \mathrm{C}$. $10 \mathrm{ml}$ of scintillation fluid (Aquasol, New England Nuclear, Boston, Mass.) was added and the filters counted in a liquid scintillation counter. To ensure that the prefiltered DNA lacked significant single-stranded areas, both the labeled and unlabeled DNA preparations were treated with a nuclease specific for single-stranded DNA (Aspergillus oryzae S nuclease, Sigma Chemical Co., St. Louis, Mo.) according to the method of Vogt (13) and the results with this preparation were compared to those obtained with DNA prefiltered only. Significant differences were not observed. The activity of the nuclease was established by its ability to render $90 \%$ of the DNA preparation perchloric acid soluble after the DNA had been denatured by heating and ice water cooling.

Sephadex G-200 serum fractionation. $1 \mathrm{ml}$ of decomplemented serum was spun at $100,000 \mathrm{~g}$ for $60 \mathrm{~min}$ and then applied to a $2.4 \times 70-\mathrm{cm}$ column of Sephadex G-200 in phosphate-buffered $0.15 \mathrm{M}$ saline, $\mathrm{pH} 7.5$. 3.0-ml fractions were collected and protein content determined by measuring absorbance at $280 \mu \mathrm{m}$. IgM was present chiefly in the first peak and IgG chiefly in the second peak as determined by Ouchterlony diffusion. Individual fractions were assayed for DNA binding activity as described above.

Sucrose density gradient ultracentrifugation. $\quad 0.2-0.3 \mathrm{ml}$ of serum was layered onto $5 \mathrm{ml}$ of a $10-40 \%$ sucrose gradient. Centrifugation and collection of fractions were carried out as described by Talal and Pillarisetty (14).

Preparation of anti- $\gamma$ and anti- $\mu$ antibodies. Antibodies to chromatographically purified IgG and IgM were raised in rabbits and the serum precipitated with $50 \%$ ammonium sulfate. The redissolved precipitate was dialyzed against phosphatebuffered saline and then passed through a Sepharose column to which either purified IgG or IgM had been bound by the cyanogen bromide method (15). After washing the columns with phosphate-buffered saline, the antibodies to either IgG or IgM were recovered by acid elution with $0.1 \mathrm{M}$ glycine $\mathrm{HCl}$, pH 3.2. To ensure specificity and remove anti-light chain activity, the anti-IgG antibodies were incubated with SepharoseIgM and the anti-IgM antibodies with Sepharose-IgG. The antibodies recovered were then tested by Ouchterlony diffusion for reactivity with $\mathrm{IgG}, \mathrm{IgM}$, and whole human serum. Anti-IgG preparations reacted only with IgG and showed a single line of identity against whole serum. Anti-IgM preparations reacted only with IgM but also had a faint nonidentical line against whole serum. These antibody preparations are subsequently referred to below as anti- $\gamma$ and anti- $\mu$ antibodies.

The anti- $\gamma$ and anti- $\mu$ preparations were individually coupled to Sepharose by the cyanogen bromide method. Specificity of the Sepharose-bound anti- $\mu$ and Sepharose-bound anti- $\gamma$ was determined by incubation with ${ }^{125}$ I-IgG and ${ }^{125} I-$ IgM. Greater than $98 \%$ of ${ }^{125} \mathrm{I}-\mathrm{IgG}$ in a preparation of human IgG $(10 \mathrm{mg} / \mathrm{ml})$ was removed by the Sepharose-bound anti- $\gamma$ and only $11 \%$ by the Sepharose-bound anti- $\mu$. $95 \%$ of the ${ }^{125} \mathrm{I}$-IgM in a preparation of human $\operatorname{IgM}(3 \mathrm{mg} / \mathrm{ml})$ was removed by Sepharose-bound anti- $\mu$ and only $7 \%$ by Sepharose-bound anti- $\gamma$.

Measurement of IgM and IgG native DNA binding activity. To determine the amounts of IgG and IgM nDNA-BA present in each serum, $0.3 \mathrm{ml}$ of patient serum was added to each of three test tubes containing $1.0 \mathrm{ml}$ of either packed Sepharose-bound anti- $\gamma$, Sepharose-bound anti- $\mu$, or Sepharose-bound normal rabbit IgG. The mixtures were incubated with periodic shaking at $37^{\circ} \mathrm{C}$ for $30 \mathrm{~min}$ followed by an additional $48 \mathrm{~h}$ at $4^{\circ} \mathrm{C}$. DNA binding was then determined on each of the absorbed sera, and the micrograms of DNA bound by IgG anti-DNA and by IgM anti-DNA were determined as follows: $\mu \mathrm{g}$ DNA bound by IgG fraction $=\mu \mathrm{g}$ DNA bound by serum absorbed with Sepharose NRIgG $-\mu$ g DNA bound by serum absorbed with Sepharose anti- $\gamma$; and $\mu$ g DNA bound by IgM fraction $=\mu \mathrm{g}$ DNA bound by serum absorbed with Sepharose NRIgG - $\mu$ g DNA bound by serum absorbed with Sepharose anti- $\mu$.

Calculation of disease activity. At the time serum was initially drawn and skin biopsies were taken, the patients were assigned an activity score which represented the sum of the number of the following disease features then present: fever, alopecia, arthritis, leukopenia, serositis, abnormal urinary sediment, erythrocyte sedimentation rate greater than $\mathbf{5 0}$ $\mathrm{mm} / \mathrm{h}$ and $\mathrm{CH}_{50}$ less than $60 \mathrm{U}$ (normal 60-110 $\mathrm{U}$ ) or $\mathrm{C} 3 \mathrm{less}$ than $65 \mathrm{mg} / \mathrm{dl}$ (normal above $70 \mathrm{mg} / \mathrm{dl}$ ).

Assessment of renal status. Decreased renal function was considered to be present when the creatinine clearance was less than $80 \mathrm{ml} / \mathrm{min}$. Renal biopsy was performed in $31 \mathrm{pa}-$ tients at or near the time of obtaining the initial samples of serum and skin. The biopsies were classified according to light and electron microscopic findings into the following cate- 
gories: diffuse proliferative glomerulonephritis, membranous glomerulonephritis, mesangial glomerulitis, or normal. The histologic criteria used for each of the classifications were as follows: (a) Diffuse proliferative glomerulonephritis, proliferative lesions involving both endothelial and mesangial cells accompanied by cellular necrosis, fibrinoid change, wire loops, or hematoxylin bodies; closure of the capillary loops and distortion of the mesangial areas; in most cases the electron microscopic finding of dense deposits in a subendothelial distribution. (b) Membranous glomerulonephritis, widespread thickening of the glomerular basement membrane with minimal cellular proliferation; in most cases the electron microscopic finding of dense deposits in a subepithelial distribution. (c) Mesangial glomerulonephritis, definite mesangial sclerosis and(or) hypercellularity involving all glomeruli or only a fraction of the glomeruli in either a local or diffuse manner; usually an increase in the amount of mesangial matrix accompanied by an increased number of mesangial cells; in most cases the electron microscopic finding of dense deposits in the mesangial matrix.

Statistical calculations. Statistical calculations were performed by Fisher's exact probability and Mann-Whitney U tests.

\section{RESULTS}

Distribution of nDNA-BA in IgM and IgG classes. Fig. 1 shows the distribution of nDNA-BA in the IgG and IgM classes as determined by immunoabsorption of the sera with anti- $\gamma$ or anti- $\mu$ antibodies. 36 SLE patients with significant $\mathrm{nDNA}-\mathrm{BA}$ in the serum were studied. In the sera of 26 patients the majority (51-

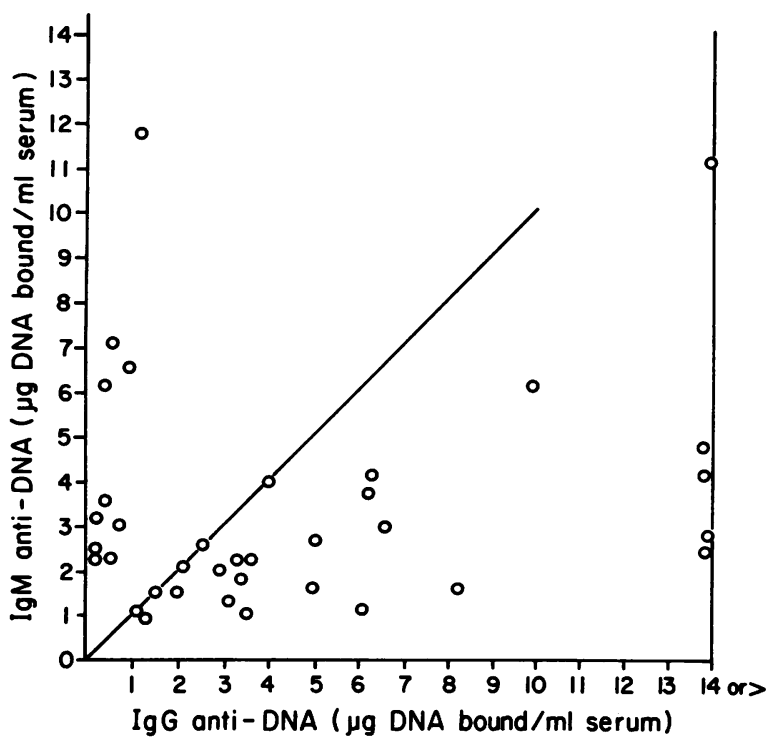

FIGURE 1 Distribution of native DNA binding activity (nDNA-BA) in IgM and IgG fractions of 36 SLE patients as determined by immunoabsorption with anti- $\gamma$ or anti- $\mu$ antibodies. The diagonal line separates those in which the majority of the nDNA-BA is in the IgM fraction from those in whom it is in the IgG fraction. Points represent the percentage of nDNA-BA measured in serum. 26 patients had $51 \%$ or more of the nDNA-BA in the IgG class; only 10 patients had predominantly (86-98\% of total) IgM nDNA-BA.
TABLE I

Comparison of Immunoabsorption, Sepharose Chromatography and Sucrose Density Gradient Methods for Assay of Class of DNA Binding Activity

\begin{tabular}{|c|c|c|c|c|c|c|}
\hline & & $\begin{array}{l}\text { uno- } \\
\text { tiion }\end{array}$ & & $\begin{array}{l}\text { dex } \\
00\end{array}$ & & $\begin{array}{l}\text { ose } \\
\text { sity } \\
\text { ient }\end{array}$ \\
\hline & IgG & $\operatorname{IgM}^{*}$ & IgG & IgM & IgG & IgM \\
\hline & & & & & & \\
\hline L. H. & 2 & 92 & 0 & 100 & 8 & 92 \\
\hline L. D. & 8 & 88 & 15 & 85 & 12 & 88 \\
\hline B. $\mathbf{M}$. & 2 & 98 & 0 & 100 & 0 & 100 \\
\hline J. S. & 6 & 86 & 7 & 93 & 13 & 87 \\
\hline W. S. & 11 & 94 & 8 & 92 & 0 & 100 \\
\hline B. L. D. & 0 & 86 & 12 & 88 & 10 & 90 \\
\hline L. T. & 0 & 88 & 14 & 86 & 14 & 86 \\
\hline L. F. & 95 & 9 & 82 & 18 & 100 & 0 \\
\hline D. K. & 92 & 18 & 88 & 12 & 64 & 36 \\
\hline D. P. & 80 & 44 & 75 & 25 & 72 & 28 \\
\hline C. $\mathbf{H}$. & 63 & 32 & 74 & 26 & 67 & 33 \\
\hline M. R. & 72 & 37 & 66 & 34 & - & - \\
\hline F. C. & 78 & 19 & 81 & 19 & - & - \\
\hline L. R. & 62 & 52 & 63 & 37 & 60 & 40 \\
\hline
\end{tabular}

* Values represent the percentage of nDNA-BA measured in the serum and therefore do not add up to $100 \%$.

95\%) of the nDNA-BA measured in the serum was found in the IgG fraction of serum. 10 patients had predominantly IgM nDNA-BA with $86-98 \%$ of the nDNA-BA in the serum found in the IgM fraction.

To evaluate the accuracy of the immunoabsorption procedure, results were compared with those obtained by fractionation of the sera by Sephadex G-200 chromatography and by $10-40 \%$ sucrose density ultracentrifugation. Table I shows a comparison of the findings obtained by the three methods in 14 patients. It can be seen that fractionation of the sera by the chromatographic and sucrose density methods followed by assay of nDNA-BA of individual fractions yielded results which agreed favorably with the immunoabsorption method.

Fig. 2 shows a detailed comparison of the three methods used in two patients. It can be seen that the peaks of nDNA-BA correspond closely to the distribution of IgM and IgG in the fractions obtained by Sephadex G-200 chromatography and by sucrose density gradient ultracentrifugation. In patient $L$. $H$. the binding activity is closely associated with the fraction containing IgM while there is little activity in the fractions containing IgG. In patient $D$. $K$. the binding activity is found chiefly in the IgG fraction. In each case the binding activity in the two classes was in agreement with the results obtained with the immunoabsorption method. 
Patient: L.H.

IgM onti-DNA

4.5 $\mu \mathrm{g}$ DNA bound/ml serum IgG onti-DNA

O.I g DNA bound/ml serum

Patient: D.K.

IgM onti-DNA

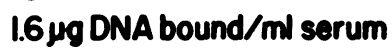
IgG onti-DNA

$82 \mu g$ DNA bound/ml serum
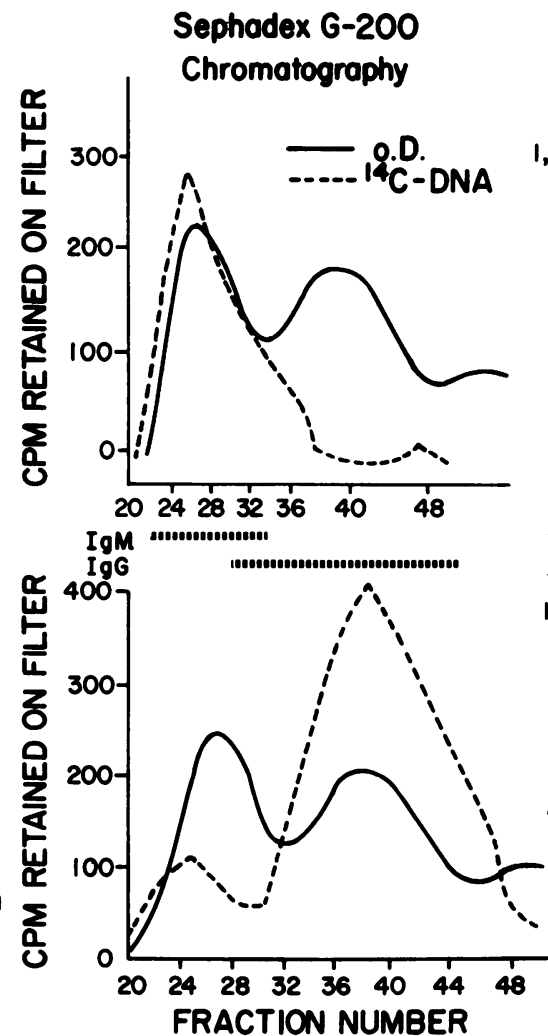

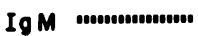

IgG

\section{Sucrose Density Grodient Ultracentrifugation}

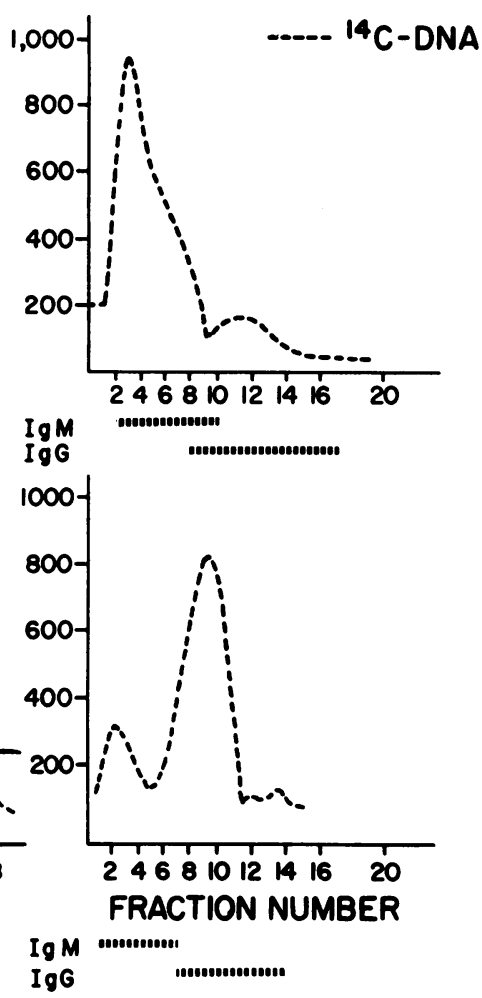

FIGURE 2 Comparison of immunoabsorption method for measurement of $n D N A-B A$ in IgM and IgG classes (values in left-hand column) with Sephadex G-200 chromatography and sucrose density gradient ultracentrifugation methods. Top tier gives findings in patient L. H. and bottom tier findings in patient D. K. (see Table I for comparison of nDNA-BA measurements). Note that the distribution of $\mathrm{nDNA}-\mathrm{BA}$ corresponds to the distribution of IgM and IgG in the separated fractions.

In Table II, the characteristics of the patients with differing class distribution of $\mathrm{nDNA}-\mathrm{BA}$ are compared. It is seen that there is no significant difference in age, sex, race, duration of disease, or prior therapy in the two groups.

Fig. 3 presents the disease activity scores of each patient at the time that the serum was examined for the Ig class of nDNA-BA. In the IgG nDNA-BA group the median activity score was 6.2 (range 1-8). In the IgM nDNA-BA group the median score was 2.0 (range 1-4). This difference, which is highly significant $(P<0.001)$, indicates that clinical activity in SLE is associated with the presence of IgG anti-DNA and that clinically inactive patients tend to have most or all of their anti-DNA in the IgM class.

Ig class distribution of nDNA-BA and renal status. Table III demonstrates the striking difference in the incidence of diffuse proliferative glomerulonephritis in the patients with mainly IgM $n$ DNA-BA and those with mainly IgG nDNA-BA. $61 \%$ of 23 biopsied patients in the IgG nDNA-BA group had diffuse proliferative glomerulonephritis while none of the 8 biopsied patients in the IgM nDNA-BA group had this severe renal lesion. Only $9 \%$ of the IgG nDNA-BA group had normal biopsies while normal biopsies were found in $50 \%$ of the IgM nDNA-BA group. The incidences of membranous glomerulonephritis and mesangial glomerulonephritis were not appreciably different in the two groups. The increased frequency of severe renal histologic changes in the IgG nDNA-BA group was reflected in the incidence of abnormal renal function in this group. 12 of 26 patients (48\%) in the IgG nDNA-BA group had creatinine clearance values below $70 \mathrm{ml} / \mathrm{min}$ while all of the 8 patients studied in the IgM nDNA-BA group studied had clearance values above $80 \mathrm{ml} / \mathrm{min}$ $(P<0.008)$.

Ig class distribution of nDNA-BA and survival. 8 of 36 patients studied died (Fig. 4) during an average follow-up period of 27.3 mo. Seven of these deaths occurred in the 26 patients with IgG nDNA-BA (27\%) and were of diverse cause. Three patients died of renal failure; two of lupus cerebritis; one of vasculitis of the 
TABLE II

Comparison of the Characteristics of the Predominantly IgM and IgG nDNA-BA Groups

\begin{tabular}{lll}
\hline & $\begin{array}{c}\text { Predominantly } \\
\text { IgM nDNA-BA } \\
\text { group }\end{array}$ & \multicolumn{1}{c}{$\begin{array}{c}\text { Predominantly IgG } \\
\text { nDNA-BA group }\end{array}$} \\
\hline Number & 10 & 26 \\
Average age, yr & 30.3 & 27.5 \\
Sex & 8 female & 22 female \\
& 2 male & 4 male \\
Race & 9 black & $\begin{array}{l}20 \text { black } \\
\text { 1 white }\end{array}$ \\
& & $\begin{array}{l}4 \text { white } \\
2 \text { Mexican-American }\end{array}$ \\
$\begin{array}{l}\text { Average duration of } \\
\text { disease before } \\
\text { study, mo }\end{array}$ & 16.3 & 16.7 \\
Prior steroid therapy & $2 / 10^{*}$ & $9 / 25 \ddagger$ \\
\hline
\end{tabular}

* Mean daily dosage, $11.2 \mathrm{mg}$ prednisolone in two patients. $\ddagger$ Mean daily dosage, $27.5 \mathrm{mg}$ prednisolone in nine patients.

small intestine; and one of gastrointestinal bleeding of undetermined origin. Eight patients in the IgG nDNABA group were receiving cyclophosphamide, chiefly for the treatment of severe renal disease. Of these, three (38\%) died. Of the 10 patients with chiefly IgM nDNA-BA, 1 died (10\%), as a consequence of opportunistic infection. One patient in this group received cyclophosphamide for treatment of the nephrotic syndrome and survived. Survival, therefore, appeared to be better in the IgM nDNA-BA group.

Relationship of Ig class distribution of nDNA-BA to class of Ig deposited at the DEJ. In Fig. 5 it is seen that the 10 patients with predominantly IgM nDNA-BA had

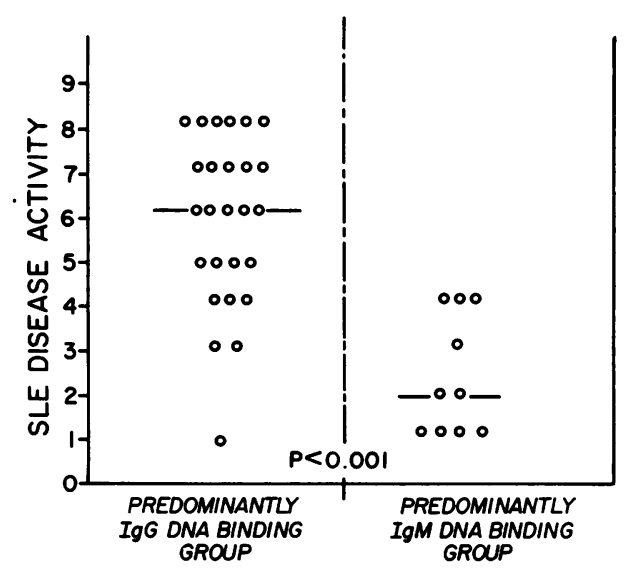

FIGURE 3 Disease activity scores of individual patients in the predominantly IgM nDNA-BA and IgG nDNA-BA groups. Horizontal bars indicate median scores for the patient groups.
TABLE III

Relationship of Immunoglobulin Class Distribution of nDNA-BA to Renal Histology and Renal Function

\begin{tabular}{lrrrrr}
\hline & $\begin{array}{c}\text { Predominantly } \\
\text { IgG nDNA-BA } \\
n=23\end{array}$ & $\begin{array}{c}\text { Predominantly } \\
\text { IgM nDNA-BA } \\
n=8\end{array}$ & P value \\
\hline Diffuse pro- & number & $\%$ & number & $\%$ & \\
$\quad$ liferative & 14 & 61 & 0 & 0 & 0.003 \\
Membranous & 3 & 13 & 2 & 25 & NS \\
Mesangial & 4 & 17 & 2 & 25 & NS \\
Normal & 2 & 9 & 4 & 50 & 0.026 \\
\hline
\end{tabular}

only IgM at the DEJ. In an average of 2.2 skin biopsies performed on each of these patients during a period of $26 \mathrm{mo}$, all continued to demonstrate IgM only in the skin. 22 of 26 patients with a majority of their anti-DNA activity in the IgG fraction of serum had both IgG and IgM at the DEJ, while only one patient had only IgM. These findings indicate a significant relationship ( $P$ $<0.001)$ between the Ig classes of anti-DNA in the serum and the Ig classes deposited in the skin.

Relationship between nDNA-BA in immunoglobulin classes and nDNA-BA in whole serum. As shown in Fig. 6, sera in which nDNA-BA was present predominantly (over $80 \%$ of the total serum activity) in the IgM class had a lower nDNA-BA than sera with nDNA-BA predominantly (over $51 \%$ ) in the IgG class. Total $\mathrm{nDNA}-\mathrm{BA}$ was $5.4 \pm 1.1 \mu \mathrm{g} / \mathrm{ml}$ for the predominantly IgM nDNA-BA group and $9.7 \pm 1.7 \mu \mathrm{g} / \mathrm{ml}$ for the predominantly IgG nDNA-BA group. However, there was considerable overlap between the two groups and the difference was not statistically significant ( $P$ $=0.089$ ).

To determine whether IgG nDNA-BA was related to severity of disease independently of total nDNA-BA, the total nDNA-BA values of eight patients in the predominantly IgG nDNA-BA group were paired with

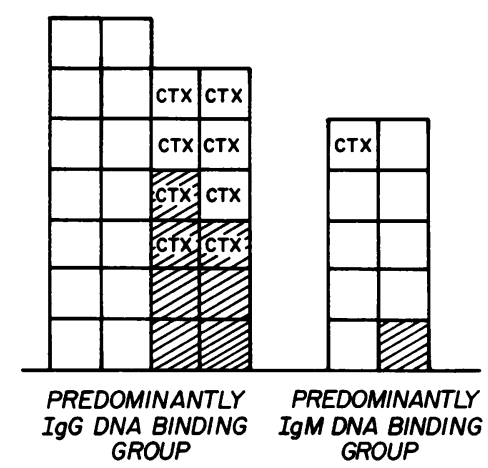

FIGURE 4 Immunoglobulin class distribution of nDNA-BA and survival. $\square=$ dead; CTX indicates patient was receiving cyclophosphamide. 


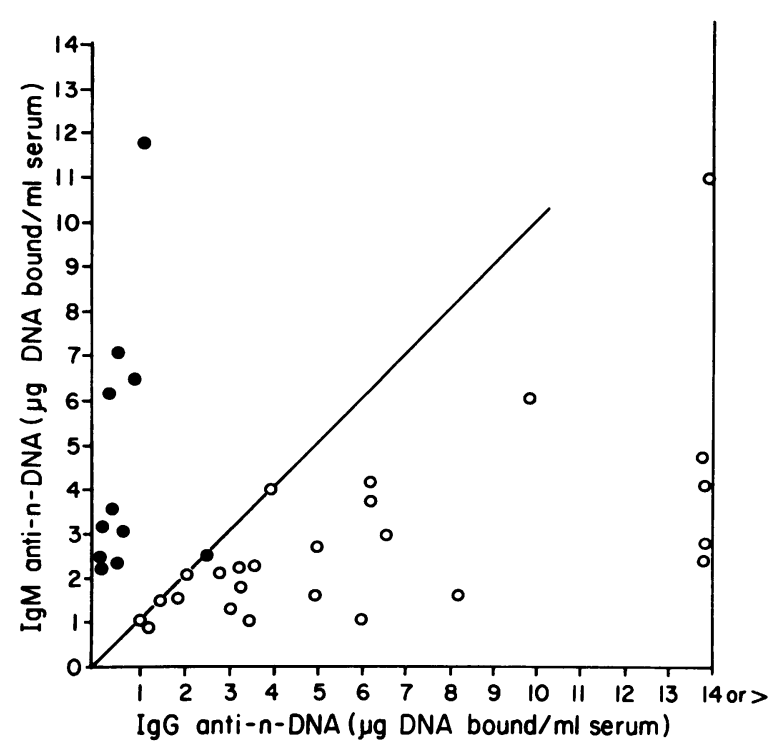

FIGURE 5 Distribution of nDNA binding activity in IgM and IgG classes and its relationship to type of Ig deposited at the dermal-epidermal junction. $=$ IgM only stained at dermalepidermal junction; $O=$ IgG or IgG plus IgM stained.

those of eight patients in the predominantly IgM nDNA-BA group on the basis that their total nDNA-BA differed by less than $1 \mu \mathrm{g} / \mathrm{ml}$. Disease activity and incidence of serious renal disease were then compared in the two groups. The median activity score of the IgG DNA-BA group was greater than that of the IgM DNA-BA group, being 6.0 in the IgG group and 2.5 in the IgM group $(P<0.05)$. Furthermore, four of the eight patients in the IgG group had diffuse proliferative nephritis, while none of the eight patients in the IgM group had this type of nephritis $(P=0.038)$. These findings indicate that disease activity and serious renal disease were related to the presence of IgG nDNA-BA in the serum even in patients with relatively low total nDNA-BA.

\section{DISCUSSION}

In this study the Ig class distribution of serum nDNA-BA has been measured in a group of SLE patients known to have nDNA-BA in the serum and Ig deposition at the DEJ. Class specific nDNA-BA was measured as a percentage of total nDNA-BA of the whole serum. Two observations have been made. First, in a minority of such patients, 10 of 36 , there was relatively limited anti-native DNA response characterized by the presence of mainly (86-98\%) IgM nDNA-BA. However, most patients, 26 of 36 , had more than $50 \%$ (51-95\%) of their nDNA-BA in the form of IgG antiDNA. The occurrence of chiefly IgM nDNA-BA in the serum was associated with lower total nDNA-BA in the serum, milder clinical disease, more benign renal his- tologic findings, and better renal function than observed in the patients with a majority of their DNA binding in the IgG fraction. Secondly, there was a good correlation between the Ig classes of nDNA-BA present in the serum and the Ig classes stained at the DEJ.

The shift from IgM to IgG antibody synthesis for most antigens is dependent upon functioning thymus-derived $(\mathrm{T})$ cells (16). The effect of thymic regulatory cells on anti-DNA and anti-RNA antibody formation has been discussed in detail by Talal (17). Thymectomized mice, lacking in $\mathrm{T}$ cells, react to thymus-dependent antigens by producing predominantly IgM rather than the expected IgG antibodies (18). Congenitally athymic, nude mice spontaneously form predominantly IgM antinuclear antibodies (19), suggesting the importance of thymic function in the production of IgG antibodies to such nuclear antigens. Roubinian et al. (20) recently studied the IgG to IgM ratio of anti-DNA antibodies in male $\mathrm{B} / \mathrm{W} \mathrm{F}_{1}$ hybrid mice and found that although the magnitude of the antibody titer was heightened by thymectomy, there was no effect on the timing of the switch from IgM to IgG anti-DNA formation which occurs later in the male than in the female. However, combined splenectomy and thymectomy resulted in an increased IgG response to DNA, suggesting that antibodies to DNA are under the control of regulatory cells present in both the thymus and spleen.

In certain strains of inbred mice, both the magnitude and Ig class of antibody response to nucleic acid antigens appear to be genetically regulated. SJL/J and $\mathrm{AKR} / \mathrm{Cu}$ mice who were high responders to proteincomplexed denatured DNA (21) produced both 7S and $19 \mathrm{~S}$ antibodies, while C57BL/6 mice, although high responders, produced only $19 \mathrm{~S}$ antibodies. At the same time DBA/2 mice, who were low responders, produced

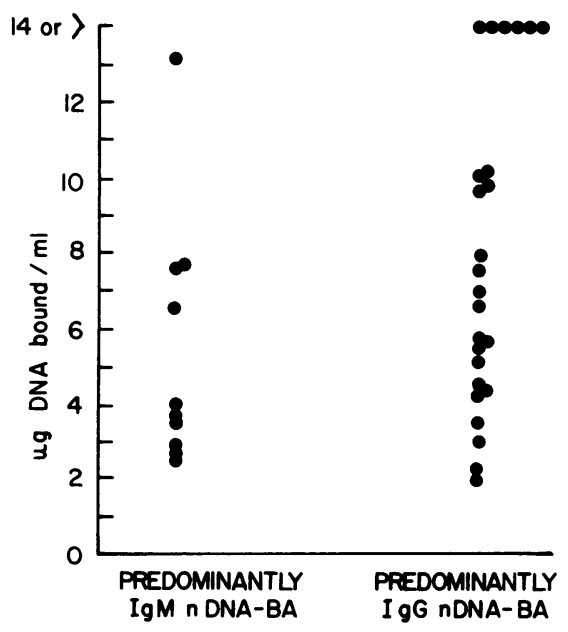

Figure 6 Comparison of total nDNA-BA of patients in the predominantly IgM nDNA-BA and IgG nDNA-BA groups. 
only a 19S response. In the present group of patients it was observed that patients with chiefly IgG nDNA-BA tended to have higher nDNA-BA in the serum, although considerable overlap in the magnitude of the antibody response between the predominantly IgG and IgM nDNA-BA patient groups was observed. In fact, when the total nDNA-BA values of patients with predominantly IgM nDNA-BA were matched with those of patients with predominantly IgG nDNA-BA and the activity scores of the matched groups compared, the patients with predominantly IgG binding activity had a significantly higher activity score than those with predominantly IgM binding activity. In addition, diffuse proliferative nephritis was present in four of the eight patients in the IgG group and in none of the eight patients in the IgM group. These findings indicate that IgG nDNA-BA was associated with more severe disease even when total nDNA-BA was relatively low. Talal et al. (22) have recently studied the immunologic regulation of antibodies to DNA and RNA in SLE patients and their family members. They demonstrated that 19S antibodies to RNA occurred in asymptomatic relatives, while both $19 \mathrm{~S}$ and $7 \mathrm{~S}$ antibodies to DNA and RNA occurred in active SLE. They concluded that SLE may be a disorder of immunological regulation with asymptomatic relatives having a partial and SLE patients a complete defect in regulation.

The observation that diffuse proliferative glomerulonephritis did not occur in the IgM nDNA-BA group but did occur in $61 \%$ of the patients with predominantly IgG nDNA-BA is of major interest. Since the age, race, sex, and duration of disease were similar in both groups, it would appear that the Ig class of nDNA-BA was a critical factor in determining whether diffuse proliferative glomerulonephritis developed. This difference was not a result of prior therapy since only 2 of 10 patients in the group without PGN had received prior treatment, and in these patients only low doses of prednisolone had been administered.

There is evidence that differences in antigen-antibody affinity and solubility between immune complexes formed by IgG and IgM anti-DNA may determine the differing incidence of nephritis observed in the presence of the two types of anti-DNA. It has been proposed that chronic immune complex disease is due to the presence of immune complexes containing low affinity antibody $(23,24)$ which tends to escape immune elimination. However, Winfield et al. (25) have recently shown that although the anti-DNA in the serum of lupus nephritis patients has low avidity, that extracted from the kidney has high avidity. Johnson et al. (26) observed that SLE patients with persistently negative DNA precipitation tests, as measured by counterimmunoelectrophoresis, had a high incidence of nephritis, while patients with consistently positive
DNA precipitation tests had a very low incidence of nephritis thus demonstrating an association of nephritis with greater solubility of DNA:anti-DNA complexes.

There is little data on the relative capacities of IgG and IgM anti-DNA to form soluble as opposed to precipitating anti-DNA complexes. Dorsch and Barnett (27) found the majority of both native DNA binding and precipitating activity, as measured by counterimmunoelectrophoresis, in the IgG fraction of three SLE sera examined. Koffler et al. (28) found a predominance of IgG deposits in the kidneys of patients with more severe lupus nephritis raising the possibility that IgGDNA complexes may produce more severe renal injury than IgM-DNA complexes. It is possible that the pentavalent IgM anti-DNA forms a larger lattice structure than bivalent IgG anti-DNA and, therefore, would be more easily phagocytosed by the reticuloendothelial system, thus diminishing the possibility of immune complex deposition in the kidney.

The patients who demonstrated predominantly IgM nDNA-BA represented a minority of those investigated. In the present study these were found among a group of 118 SLE patients in whom the pattern of Ig staining of the DEJ was examined. Only 14 of the 118 patients demonstrated IgM alone at the DEJ junction. ${ }^{2}$ Of these 14 patients, 3 showed no significant DNA binding activity in the serum and 10, whose nDNA-BA could be measured, had predominantly IgM nDNA-BA. Only one had appreciable quantities of IgG antibody. On the other hand, all 25 patients with IgG or IgG plus IgM at the DEJ had predominantly IgG nDNA-BA in the serum. This correlation between the Ig classes of serum nDNA-BA and the Ig classes present in the skin strongly suggests that the classes of Ig deposited at the DEJ are primarily determined by the type of anti-DNA present in the serum.

\section{ACKNOWLEDGMENTS}

This investigation was supported by U. S. Public Health Service Program/Project grant AM-09989, Research grants AM18505 and AM-19101, Training grant AM-05154, a Dermatology Foundation grant, and an Arthritis Foundation Clinical Study Center grant.

\section{REFERENCES}

1. Schur, P. H., and J. Sandson. 1968. Immunologic factors and clinical activity in systemic lupus erythematosus. N. Engl. J. Med. 278: 533-538.

2. Koffler, D., P. H. Schur, and H. G. Kunkel. 1967. Immunologic studies concerning the nephritis of systemic lupus erythematosus. J. Exp. Med. 26: 607-623.

3. Picazo, J. J., and E. M. Tan. 1975. Specificities of antibodies to native DNA. Scand. J. Rheumatol. 11: 35-41.

4. Gonzales, E. N., and N. F. Rothfield. 1966. Immunoglobulin class and pattern of nuclear fluorescence in

${ }^{2}$ Gilliam, J. N. Unpublished observations. 
systemic lupus erythematosus. N. Engl. J. Med. 274: 1334-1338.

5. Tojo, T., G. J. Friou, and H. L. Spiegelberg. 1970. Immunoglobulin $G$ subclass of human antinuclear antibodies. Clin. Exp. Immunol. 6: 145-151.

6. Tojo, T., and G. J. Friou. 1968. Lupus nephritis: Varying complement-fixing properties of immunoglobulin $\mathrm{G}$ antibodies to antigens of cell nuclei. Science (Wash. D. C.). 161: 904-906.

7. Rothfield, N. F., and B. D. Stollar. 1967. The relation of immunoglobulin class, pattern of antinuclear antibody, and complement-fixing antibodies to DNA in sera from patients with systemic lupus erythematosus. J. Clin. Invest. 46: 1785-1794.

8. Papoian, R., R. Pillarisetty, and N. Talal. 1977. Immunologic regulation of spontaneous antibodies to DNA and RNA. I. Sequential switch from IgM to IgG in NZB/NZW $\mathrm{F}_{1}$ mice, Immunology. 32: 75-79.

9. Gilliam, J. N. 1976. Comparison of immunoglobulin (Ig) classes and frequency of subepidermal deposits in female and male NZB/W mice. Arthritis Rheum. 19: 797.

10. Cohen, A. S., W. E. Reynolds, and E. C. Franklin. 1971. Preliminary criteria for the classification of systemic lupus erythematosus. Bull. Rheum. Dis. 21: 643-648.

11. Gilliam, J. N., D. E. Cheatum, E. R. Hurd, P. Stastny, and M. Ziff. 1974. Immunoglobulin in clinically uninvolved skin in systemic lupus erythematosus. Association with renal disease. J. Clin. Invest. 53: 1434-1440.

12. Ginsberg, B., and H. Keiser. 1973. A millipore filter assay antibodies to native DNA in sera of patients with systemic lupus erythematosus. Arthritis Rheum. 16: 199-207.

13. Vogt, V. M. 1973. Purification and further properties of single-strand-specific nuclease from Aspergillus oryzae. Eur. J. Biochem. 33: 192-200.

14. Talal, N., and R. Pillarisetty. 1975. IgM and IgG antibodies to DNA, RNA, and DNA:RNA in systemic lupus erythematosus. Clin. Immunol. Immunopathol. 4: 24-31.

15. Frommel, D., J. M. Dupuy, G. W. Litman, and R. A. Good. 1970. Use of immunoabsorption techniques in the preparation of chemical agammaglobulinemia. J. Immunol. 105: $1292-1293$.

16. Katz, D. H., and B. Benacerraf. 1972. The regulatory influence of activated $\mathrm{T}$ cells on B-cell responses to antigen. Adv. Immunol. 15: 1-94.
17. Talal, N. 1976. Disordered immunologic regulation and autoimmunity. Transplant. Rev. 31: 240-263.

18. Davie, J. M., and W. E. Paul. 1974. Role of T lymphocytes in the humoral immune response. I. Proliferation of B lymphocytes in thymus-deprived mice. J. Immunol. 113: 1438-1445.

19. Monier, J. D., and M. Sepetjian. 1975. Spontaneous antinuclear autoimmunization in swan and nude mice: Comparative study. Ann. Immunol. 126C: 63-75.

20. Roubinian, J. R., R. Papoian, R. Pillarisetty, S. Sawada, and N. Talal. 1977. Immunologic regulation of spontaneous antibodies to DNA and RNA. Early effects of neonatal thymectomy and splenectomy. Immunology. In press.

21. Fuchs, S., E. Mozes, and B. D. Stollar. 1975. The nature of murine immune response to nucleic acids. J. Immunol. 114: $1287-1291$.

22. Talal, N., R. J. Pillarisetty, R. J. De Horatius, and R. P. Messner. 1976. Immunologic regulation of spontaneous antibodies to DNA and RNA. I. Significance of IgM and IgG antibodies in SLE patients and their asymptomatic relatives. Clin. Exp. Immunol. 25: 377-382.

23. Soothill, J. F., and M. W. Steward. 1971. The immunopathological significance of the heterogeneity of antibody affinity. Clin. Exp. Immunol. 9: 193-199.

24. Petty, R. E., M. W. Steward, and J. F. Soothill. 1972. The heterogeneity of antibody affinity in inbred mice and its possible immunopathologic significance. Clin. Exp. Immunol. 12: 231-241.

25. Winfield, J. B., I. Faiferman, and D. Koffler. 1977. Avidity of anti-DNA antibodies in serum and IgG glomerular eluates from patients with systemic lupus erythematosus. Association of high avidity antinative DNA antibody with glomerulonephritis. J. Clin. Invest. 59: 90-96.

26. Johnson, G. D., J. P. Edmonds, and E. J. Holborow. 1973. Precipitating antibody to DNA detected by two-stage electroimmunodiffusion. Lancet. II: 883-886.

27. Dorsch, C., and E. V. Barnett. 1974. The occurrence and nature of precipitating antibodies in anti-DNA sera. Clin. Immunol. Immunopathol. 2: 310-321.

28. Koffler, D., V. Agnello, R. I. Carr, and H. G. Kunkel. 1969. Anti-DNA antibodies and renal lesions of patients with systemic lupus erythematosus. Transplant. Proc. 1: 933938. 